\title{
合成纎維に關する二、三の問 題*
}

（昭和25年9月24日受理）会員荒井溪 吉"*

\section{1. まえがを}

我国に打汀る合成繊維の既に工業化の段階に進められ たものに倉敷レーヨン、镜紡、大日本紡、東拌レーヨン、 日セル、日窒等あり、慎重研究を反復しているるのに、 新光レーヨン、東着レーヨン、帝人、旭化成、富士紡、東 羊紡、日清紡、大和紡、敷島紡、日東紡等があり、その成 敗如何は、単に繊維諸会社、化学工業会社だけてなく国 民一般の重大なる関心事になつている。勿論、現在の合 成繊維は、幾多の長所と共に幾つかの久点を有している か、今や各社各工場各位の真剣なる努力によつて、その 欠陌は、一日一日と是正修正せられ、日進月步、その品質 か向上し、又原価の低减も誠に顕著てある事は、全く他瀻 維工業に見られない独自の現象である例をヒニロンに ついて見ても、その工場原価はここ1ケ年にるる减少した 諴に着目すべき事実てある。アミランに执いても原価の 低域は勿論、その断然たる性質の優良性は、類似構造を持 つナイロンによつて既に立証されている。原粗資原の閏 沢なる供給を得るなれば、その発展は期して待つへきで あろら。

合成繊維といつてもその種類は極めて多く Nylon, Amılan, Vinyon, Vinylon, Salan の外 Orlon, Rohvyl, chemistrand, Perlon, Telyleue 等米、独、佛、英等一流 科学国に颃いて、盛灶業化分現に促進されて括り、然子 それそれか、その製造機栈、及び設備條件を異にするのて 到底これを尺すことは等来ないが、便宜上、ビニロンを 例にとつて見ると、次の諸点か目下一般の問題とされて いるよろである。

(1) 研究室で立哌に出来た緎維を、工場に拉い工業 的に如何に均一に然む廉価に作るか。

（2）而熱水性の低い点をどう克服するか。

(3) 染色かどうるらまく行か炇事はどう解決するか。 である、( 2 )及び ( 3 ) は物理、化学的問題か主であり、 さる4月10日高分子化学協会の講演に扔いて桜田一郎敉 授は、これ等の改善の具体策として、極めて含蓄ある示唆 を与えられているが (1)の問題に関しては、密ろ機械 学的な問題か多く残つている。而熱水性の問題にしても 所定の熱処理を完全に実施し、フォルマリンによるアセ タール化を行ら普通のビニロンです、クロルアルテハイ ト $\left(\mathrm{Cl} \mathrm{CH}_{2} \mathrm{CHO}\right)$ でア女タール化したビニロン $\mathrm{C}$, にしても、実驗室的な規模において、各繊維に処定の処
理を施したならば、乾、湿の强力比率は 80 \%以上出る のか当然であり、且つ、常に $120^{\circ} \mathrm{C}$ において1時間以、 上は何等変化はない筈であるから、従つて常圧に括ける 沸滕熱水に颃、て即ち普通の染色加工処理又は冼條によ つて何等影響かないのか当然であるにも拘らず、間々、 久陷あるビニロンが出来ることは、要すれば、各繊維に及 ぼす、均斉処理の機構に機栈的な久陌かある事に基く。 又、染色性の問題にしてる何等の研究を行わず、従来の既 存繊維、綿、羊毛、レーヨン、レーヨン・ス・フの取扱い をその末まどニロン繊維に適用していることに基く欠陌 か多く見られ、且つ染着性に多少の差異はあつても実際 の使用途力適当てある場合には、何等支障かない箱であ る。（染色に関しては瀻維学会関西支部発行の吉武敋授 による合成纎維の染色を参照されたい)のみならず、ビ ニロンの熱処理後、クロルアルデハイドヌはブロムアル デハイトでアタール化し、後、エチレンダイアミン $\mathrm{H}_{2} \mathrm{~N}-\left(\mathrm{CH}_{2}\right)_{2}-\mathrm{NH}_{2}$ 又はアムモニア等のアミン類を 作用せしめて、アミノ基を導大した所謂ビニロン A N は、酸性染料に対する染着性を高め羊毛と極めて近い染 着性を示し得るか、（この研究に関し山本晃氏の真剣な 努力を特に称えたい)この場合、エチレンヂアミンにし ても、アムモニャを用いるにしても、類似のアムモニア 臭を出す瓦斯の始末を、とうするかか帮際の工場となる と、相当考えなけれはならない。香も角耐熱水性にしてる 染色性にしても、目下世間て湩々さわかれている程問題 でく、寧ろ、問題の核心は笑驗室て立哌に出未た瀻維 を工場生座に怙いて、如何に、均斉に、且つ廉価に、作り 得るかの機械設備の改良考案に今後の真剣な努力か行わ れなけれはならない時期に至つている。又この点に関し 現に各社各工場によつて日夜真剣に研筫力行われつつあ る。この問題に関しても原料の石炭、石灰の処理から、 瀻維製品となつた後の整理加工になると、極めて範囲は 㕕いが、今日は単にビニロンに止まらず広く合成瀻維一 般につき紡出から、纎維後処理まての工程に括ける、主 要問題について瀻維機㭜学的立場から二、三の提案をし ようと思万。

\section{2. 合成綧維に關する二、三の問題}

(1) Linear chain molecule の纎維長 (M.F.Lの問題)

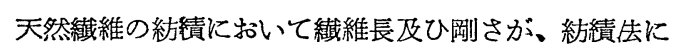
極めて大きな影響を与えていることは余りにも衆知のこ 



のものか、天然纎維の紡績の如く、眼に見えないにしても 新鋭高分子分質てあることには変わりはなく、これを糸 に紡糸出来るためにはその微小繊維の繊維長そのものか 相当長いことか條件てある。早い話しかビスコース、レ 一シンに拈いて $\gamma . \beta$ セルロースを使用したり、グラン ドパルプを使用しては、よいレーシンか紡出されないこ とは、321n以下の天然繊維ては、よい精糸を紡績し難い のとよく似ている。人造繊維に执いても、決して繊維長 を問題にしていないわけてはなく、これに相当するすの として重合度を取扱つている。ヒスコース法において、 重合度 300 とか 500 とか称する所以てある、これは萄 葡糟の単体か、300 とか 500 とかの個数たけ、連結して いることを示す。W. H. Haworth によると単体の周期 の長さは $103 \mathrm{~A}$ であるから、萄葡㷮の 2000 連結した 綿花においては各鎮状分子の長さ Lc は

$$
\begin{array}{ll}
\mathrm{Lc}=\mathrm{L} \times \mathrm{M} \times 1 \% & \mathrm{~L}=10.3 \AA \\
=10.3 \times 10^{3} \AA & \text { となる }
\end{array}
$$

ところか普通のレーヨン、ス・フに捈いては $M=200 〜 300$ 程度てあるふら便宜上 200 とするとレーきンの各鎖状 分子繊維の長さ $\mathrm{L}_{\mathrm{R}}$ は

$$
\mathrm{L}_{\mathrm{R}}=10.3 \times 10^{2} \AA=1.03 \times 10^{3} \AA \text { となる。 }
$$

立川正三氏の所謂虎木棉（現在の鐘糼防府工場）におい は䄸リンターを使用し、紡杀條件を変えて、M を大 きくするようにしてあるので、丁度 $\mathrm{L}_{\mathbf{T}}$ は $\mathrm{L}_{\mathrm{c}}$ と $\mathrm{L}_{\mathrm{R}}$ の 中間に位置しているし、乾湿强度比当普通のレーミンよ りも遥に高い、ところか各連の合成纎維が現われて来る と、単体の長さか各璉各樣であるので、重合度だけて鎖 状分子の纎維長を示さないことになる。今ナイロンを例 にとると、纎維単体の長さは $17.2 \AA$ である、（桜田、 開野氏による) 従つて、重合度、200 の Nylon の分 子繊維長 (Micro, Fiber Length or. M F. L ) $L_{N}$ は

$$
\mathrm{L}_{\mathrm{N}}=17.2 \AA \times 200=3.44 \times 10^{3} \AA
$$

即ち Nylon の重合度 200 のものと Viscose Rayon の 度合度 200 のものとては M F. L か約 3 倍子違万。 他の合成繊維でも X線分析によつてそれそれの単体の緎 維軸長を測定して拈けは、当然それそれの M. F. L か 重合度によつて、算出される。従来のように人造瀻維が 繊維素系のものたうけのときは、重合度を則定しておけば M. F. L はHたか

即ち M. F. L. Celluloses 重合度 $=$ K. M

各種合成繊維力現われて来ると、単体の繊維軸長 $\mathrm{K}_{\mathbf{x}}$ か それそれ異なつているのて 即ち $\mathrm{K}_{1} \neq \mathrm{K}_{2} \neq \mathrm{K} 3 \cdots$ で あるので重合度、M の測定たけで M. F. L は決められ ない。

嘗つてレーきン、ス・フかスケ間敷しかつた頃、(昭和 12,3 年頃) ス・フの紡瞔に際して、ス・フの繊維長を 長くさえすれは糸の引張り強力かいくらでも大きくなる
といら賤論か盛んに横行して、ス・フの割当問題にまて からんて来た頃、佐分利、荒井は詳細な、凑驗事実と理 論を示して、ある程度以上、瀻維長を長くしても、糸の引 㲀り强力は増加しない事を立証して、この問題の決着を つけたことかあつたが、人造繊維においてす、M. F. L を綿密に精查することによつて、この事実か行なわれる ことか理解、且つ立証せられるであろろ(第1図) 鬼も 角合成繊維の品質、改善のために、M F. L かもつと 高く檢討さるべきである。・

(2) M.F.Lの均斉度(重合度の均斉度-)M.S. Dの問題 重合度の則定法としては彷来、粘度法、透任丢、超 心失、未端基丢等かあるか、普通には最も多く粘度法が 行われている。これは本均重合度の大小を示するのであ つて、決して各鎖状分子の重合度分布を示するのではな い。天然紡積で問題となるのはステープル、ダイヤグラ ムである、あらゆる紡嘖㙨峨を决定する要素の中 staple length が、その大きな役割を占めることは、刎論である か、更に均斉な糸を紡嗊するためには、更に繊維長の均 斉度方問題になる。棉花、羊毛に打いて良糸を紡績する ためには、コーマー掛计をするが分子紡嘖においても当 然このことか考えらるへきた。粘度佉によつて重合度を 調べる場合、平均重合度はわかつても、重合度の分布か 不明たとすれは、よい分子紡績丢をなすためには透圧 法その他を採用して M. F.L の相異をしらべなければ ならない。

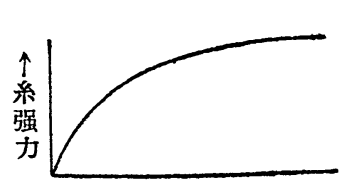

(第 1 国)
M.F L (るはF.L)

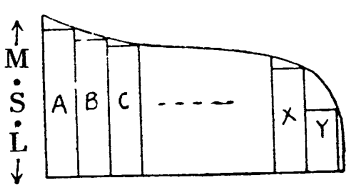

M. S D
(ミグロ・ステープル $)$

(第 2 龱)
今、滲透任法の重合度をMo

粘度佉の重合度を $\mathrm{M} \eta$ とすれば

$$
\frac{\mathrm{Mo}}{\mathrm{M} \eta} \leqq 1
$$

Perfect Linear Construction をなす場合のみ $\mathrm{M}=\mathrm{M} \eta$ 従つて、M. F. L を決めるためには、先づその高分子物 体の構造如何をはつきりさすことか先决問題になる。 鎖状高分子物体の M. F. L の分布状態即ち、Micro Staple Diagram (M. S. D) を決定するためには、先 づ micro fiber を分別炕㩔法に基いてそれそれの M. F を溶偊に別途にとかして分別し、それそれの各部位の 透圧を則定し、それそれの重合度即ちＭＦ．Ｌをを則 定しこれ等 A.B ……XY (第 2 困) を組合わせること によつて M. S. D の近似形を作冬することか出来る 文粘度法によつてもその回数を多くし、これを適当に整 理することによつて、M. S. D の近似値を得られる。 
最近における外国の研究報告においては $\mathrm{M} \eta$ のみなら ず、Moを併用した重合度測定値を併記したものを多数見 かけるようになつたことは、これ等の研究が系貿の敋善 のために、極めて重要でることを示唆しているすのと 思われる。天然緎維の紡績と同じく分子紡績即ち、レー ヨン文は合成瀻維の紡出においても、均斉な精系を得る ためにはこの M S. D か極めて大切な役割をはたす。 即ち、この M. S. D はH来るだけ本らなるのがよい。 言葉を变えていえば M. F. L のひん度曲線はシャープ なのがい、即ち重合度又は M. F. L の搠つたものが 望ましい。これは単に Synrthetic Fuberに限らずレーき ンに掂いてあいえることである。レーヨンに拉いて、紡 系直前に揃つた重合度のもの、一樣な.M. F. L のもの を得るためには浸清、粉砕、熟成、老化、溶解の全工程 に亘つて十分な考慮を拂万外、更に原料パルプの製造に 際し、原木の選択からチップ形成、更に溶解に至る全工程 に亘つて特に、溶解機構に强き反省を加えねばならない。 又合成繊維においては粒状、乳化その他の重合丢のメカ ニヅムに强き機峨学的、物理化学的反省を加えなければ ならないのみならず紡糸直前に更に、それぞれの合成緎 維に適合した特殊溶剤を使用して、低重合度即方 short micro fiber. leugth のものを除することを当然考え ねはならない。

(3) Linear chain molecule の㴊硬度

合成瀻維においてはビニール系、ポリアミド采にかぎ らず炭素を主鎖原とする場合か多い、ダイヤモンドは炭 素の四つの手か立体的に均斉な手て完全に繫かり相互間 隔か $1.5 \AA ゚$ であることはよく知られたことであるが、か かる立体構造の結晶をなすとき而熱性はケタ違いに大き くなり、同時に各種藥品に强靱であるはかりでなく、硬 度もまるて大きくなる、然し炭素力二次元的の方向に結 晶をなすときには石、墨となつて、その性質か大部かわり 更にビニール系高分子物、ポリアミド系高分子物の如く Linear の方向に一次元的な配列を窗すときには、パラフ イン、ナイロン、ビニロン、アミラン等の如く柔軟なも

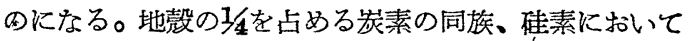
あ同樣のことかいえる!すなわち三次元的な立体構造の 結晶をなせば、承晶となり、二次元的な本面構造の結晶 をなせば雲母となり、一次元的な方向につなかれば石棉 となつて紡嘖原料に使用される。即方、柔軟度というか。 岡硬度というか、この結晶構造如何か、物質の物理化学 的性貿を決定する根基になる、合成瀻維を形成する炭素 鎖かそれぞれとらいう風につなかり合らか、その手かと れだけ動き得るかか、分子瀻維の剛硬度を決める要素に なる。ここに炭素の自由廻転性と、束縝回転性の論䈉の結 着か大事となる所以である。今両用の意見が世界て問題 にされているか、(第 3 図) 乘あ角ポテンシャル、ミニ アムの位置に安定せんとする傾向にあることはあたりま
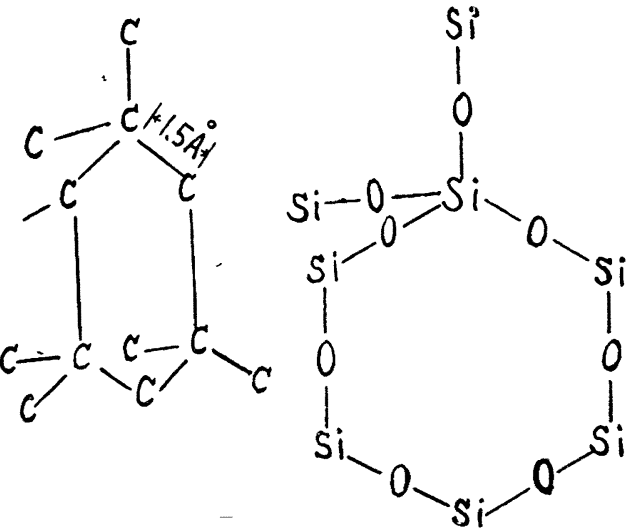

ダイヤモントの結晶

(第 3 困)
えのことである。

目下ナイロンの品質改善のために架橋構造力墭に研究 されている。塩化ビニールに関しても、その架橋機構が 問題になつている。従来ビスコース、レーヨンに拮いて、 高重合度のるのは紡出か至難だとされていたかてれは必 らずしも M. F. L か長すきて紡出か出来ないとい5の はてなく、高重合度の R，P を作万弓とするときには変 解 (Dijestion) か十分に行い得ず、従つて緎維素のミ セル構造の分離を所期の大きさにまで進行し得ず ため にアルカリ浸責、老化の反応において、単一鎖状分子を 十分に分離出来ず、一部难結晶構造の繊維束、未溶解緎 維として工程間を運はれるために濾過機等において取り のそかれ、結局、紡糸ノッ゙ルまて達するものは低重合のあ のか多いという結果になつて紡出不能の現象を起すであ ろらことの方かより强く考えられる。塩化どニリデン緎 維てあるサラン織維に拉いて1.5D というような細い 繊維の見当らないのあ女る意味でその構造の架橋組織を 暗示しているものとも思方る。

乘も角合成纎維の各喠物理化学的性、質の改善向上を はかるために、単に重合度や M. F L M. S. D. のみ ならず、その架橋組織の研究に更に大念な研究か反復さ るべきである。

（4） viscous fluid の均肴な送出しとノッ゙ルの配置

湿式紡系の埸合には viscosity 分低いからさほと問題 にならないか、合成繊維の出現によつて半乾式紡系、乾式 紡糸か行なわれ、然す高い、M. F. L のものを使用する に從つて、viscosity かとんどんと高くなるので、この 場合、粘度に応じてノッ゙ル穴のあけかたや相互間隔や、 配置の樣子を相当考えねばならない今、高粘度の用いる 場合す従来の樣に円型のノッ゙ルを使用すると、大さの一 樣な真直くな円筒内の流れと見ることか出来るか（第 4 田) 


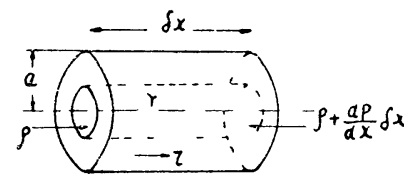

ノッ゙內の县力平衡
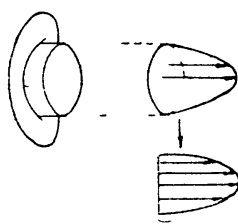

速度分布曲線

\section{(第 4 図)}

今図に括いて半径 $\mathrm{r}$ の長さ $\delta x$ の円杜の底面にはた らく代力差による力は $\pi \mathrm{r}^{2} \frac{\mathrm{dP}}{\mathrm{d} x} \delta x$

円桂の周囲にはたらく v1scosity に基く $\tau$ による力は $2 \pi \mathrm{r} \tau \delta x$

$$
\begin{aligned}
\therefore \quad & \pi \mathrm{r}^{2} \frac{\mathrm{dp}}{\mathrm{d} x} \delta x=2 \pi \mathrm{r} \tau \delta x \\
\tau & =\frac{\mathrm{r}}{2} \frac{\mathrm{dp}}{\mathrm{d} x} \quad \text { or } \mu \frac{\mathrm{du}}{\mathrm{d} \mathrm{v}}=\frac{\mathrm{r}}{2} \quad \frac{\mathrm{dp}}{\mathrm{d} x} \\
\mathrm{u} & =-\frac{1}{4 \mu} \frac{\mathrm{dp}}{\mathrm{d} x}\left(\mathrm{a}^{2}-\mathrm{r}^{2}\right) \quad \mathrm{v}=\mathrm{a} \quad \mathrm{u}=0
\end{aligned}
$$

すなわち viscosity の変化によつてその山の形ちは異 なるか、何れにせよ、ノッ゙ルの配置穴経等によつて、速 度の変化か与えられないとすれば、速度分布曲線は中央 そ中高の曲円境をなし、その速度の変化の傾向は、 viscosity か高くなるにつれて、即ち、高粘度の合成㵶 維の溶融紡糸の場合等においては、离その差か激しくな る。即ちノッ゙ルの穴の位置如何によつて送出される放量 か異なつてくるから、従つてデニール簇を生ずる。即ち 普通のレーシンの如く粘度の低いものにおいてはこれに 基く糸の簇はさしつかえのあるほとはけしくはないか。 M. F. L の高い高粘度のビスコースや、ナイロンその他 の合成繊維を取扱了場合には紡出ノッ゙ルの穴の形のみな らず穴の配置についても十分な配慮をなす必要かある。 要すれば、ノッ゙ルの穴の中心を中心とする同心円上に穴 を配置することは勿論、むしこれを 2 列又は 3 列にして 生產高を 1 錘当り上ける場合には、viscosity の変化に 応じて、各列毎の穴の径を上远の速度分布と逆にノッ゙ル の中央に行くにつれて少さくしなけれはいけない。ビス コースむレーヨンからス・フになるにつれて、1銛当り 生产高を増加することと、系切を防止するために、穴呚 は 1000 から 20003000 とあかつて来ているか、合成 繊維に括いてるエンドレスから、ス・フになるにつれて 所要機狘設備を少なくし、工場生原価を少なくするた めには当然、この傾向はとらるべきであり、従つて、穴 型、穴の位置配置、穴の直径等は紡系後の延伸如何と関 連して、慎重に算出檢討すべきである(後略)

\section{3. あとが き}

かつて Du, pon 社かナイロンを発表し、これをさか んに宣傳していた頃、まだ手をつけていない会社や、研
究室から盛んにナイロンの欠点をつく反対意見が陸続と して発表され、我国に战いてもこれに同和した人達す少 くなかつた。日く、ナイロン靴下はローのような感じで。 はくとから゙れて来る、日く、ナイロンは丈夫は丈夫だが さえた色か染上らないから䭾目た、日く、吸湿性かなく、 保温性かないから、は代着や冬服地にはむかない、日く ストーフにあたつたら溶けてしまつた。ところか現実は どうか、当時のこれらの非難を余所にして、改善に改善 を加え、増產に増差を続け、既に年間生量 7000 万lb を越え、更に各喠の類似合成纎維か世界一流国家群に よつて続々作られる等第三次繊維革命は現に進行中てあ り、绲紡、混織、プレキソンによつて、既存の綿、羊毛 人絹工業も更に面目を一新しつつある、このことに類似 した現象は我国のレーヨン、ス・フに执いてる見られる ス・フは弱いるの、悪いるの、高いあのの代名詞てあつ たのは全〈過去の夢てあり、オールレーミン、ス・フ の織物に純綿の捺印を押して賣出されたり、ス・フ入り の羊服地の方か賣れ行きかよい時代にさえなつた。全く 科学の力てある、今この合成緎維の宿命的な発展段階に あたつて、筆者の以上流へ来つた要点を要迅するなれば 次の如くてある。

a 、合成繊維に斿いてす勾肴な良い品を廉く作るた めには機峨学的な綿密な、研究配慮か、絶対に必要であ り、機㧴屋はこの際化学者、物理学者に欣然拹力すべき である。

b. M. F. L 合成緙維 (レーシンを含む意味の) の品質改善のために M. F L (Micro. Fiber Length) 微分子繊維長を考えるべきであり、単なる重合度たけで は不十分である。

c. M. S. D 一均彥なよい合成繊維（化学繊維一 般)を得るためには M. S. D (Micro Staple Diagram を再檢討し、レーヨンにおいてはパルプの製造から紡系 に至る全工程の機械的処置を吟味して均彥度 (evenvess) の向上に努め純合成繊維においては主として重合反応以 降、紡糸に至る全般に亘つて、M. S. D の均斉化の努力 力を尽すべきである。

d. 結晶構造一一合成纎維の結暃構造如何は糸、織 物の品質に極めて大きな影響を与える。鎖状高分子物 質か糸の中てとろいう構造をなしているかと共に、その 鎖状高分子物質そのものか系の中てとういう姿であるか 現実の樣子をはつきり攂末えることか大事である。

e. 紡糸ハヅル口の配置一個々のノッ゙ルの形穴径 等については従来相当研究か進められているか、穴の配 置、等に括いては比較的未開拓の分野か多い。特に高い M. F. L のすの、高枮度のものを取扱うことの多い合 成瀻維火括いては、穴は同心円上に配置し、且つ数列を 用万るときその各列の穴経は粘度によつて変更さるべき である。 